\title{
ALCOHOL AND THE WAR: FURTHER EVIDENCE FROM THE CONTINENT.
}

\section{BY JOHN NEWTON.}

THE movement against the use of alcohol as a means of promoting the physical and mental efficiency of the nations involved in the great world-war continues on the Continent with unabated vigour. As the stress of the gigantic struggle in which civilization is fighting for its life is more and more felt, the minds of the leaders of men, realizing their terrible responsibility, seem to be turning steadily against alcohol becuuse of its crippling effects upon mankind. Not only our Allies, but our enemies have taken, or are taking, steps to limit, if only partially, the use of alcohol both by troops and by civilians.

I am indebted to Dr. Hercôd, of Lausanne, the editor of several international journals and a competent authority on the subject, for several items of information regarding the action of Germany, Austria, and Switzerland, which he has specially supplied to me at my request.

\section{THB ACTION OF OUR ENEMIES IN REGARD TO ALCOHOL.}

In Austria no restrictions were put upon the sale of alcohol during mobilization, with the result that there was much drunkenness with its attendant evils. Recently the military authorities have interfered so far as to stop the serving of soldiers with liquor at railway-stations, and the civil authority decided in February last that no more barley should be used for brewing purposes.

In Germany mobilization took place under considerable restrictions, as neither wine nor beer could be supplied at the railway-stations to the troops, nor in the immediate neighbourhood of the stations. 
On the field there is no uniform rule. Some commanders prohibit intoxicants, others favour them. The Crown Prince distinguished himself by publicly asking for more rum for the troops. Much indignation was aroused in certain quarters by his action. Some military commanders of garrison towns have prohibited the treating of soldiers, and are particularly severe on those who treat wounded soldiers.

The Provincial Governments of the German Empire have been given power to close all spirit shops in their respective areas if they so desire; and throughout the Empire the amount of beer which can be brewed has been reduced to 40 per cent. of the customary amount in order to preserve barley for bread.

\section{ALCOHOL IN NEUTRAL SWITZERLAND.}

In 1908 Switzerland, by a vote of the whole people, prohibited the manufacture, importation, and sale of absinthe. Neither the Federal nor the Cantonal authorities have taken any action against alcohol since war broke out, but the Commander-in-Chief of the Swiss Army has acted in the interests of the soldiers. At the end of April he issued a general Army Order in which he declared that it was admitted that the greatest part of the offences committed by the soldiers under his command was due to alcohol, and that the use of alcohol was detrimental to military efficiency. The inn-keepers were told to sell non-alcoholic drinks at low prices to soldiers, and if they failed to do so, the soldiers would be prohibited from entering their houses. The officers were enjoined to speak to their men about the importance of sobriety, and to take care that they set a good example in this respect. In some importarit military centres-such as Basle, for instance-all sale of spirits to soldiers was forbidden.

Efforts are being made in various parts of Switzerland to provide temperance reading and recreation rooms as counterattractions to the public-houses.

This is what the military authorities of a neutral country regard as necessary in order to preserve the good conduct and efficiency of their troops. We, who are at war, might at least do as much for our own men.

\section{ALCOHOL AND OUR ALLIBS.}

In Italy, as far as information is available at the time of writing, the only incident worthy of mention was the attempt of the 
Members of Parliament for Sicily to persuade the Minister of War to increase the allowance of wine to the soldiers in case of war. This the Minister peremptorily refused to do.

In France the prohibition of absinthe came none too soon, as its ravages were showing themselves on a large scale: "Absinthe drunkenness is accompanied by convulsive phenomena and hyperæsthesia, and is thus differentiated from other forms of drunkenness. Other features are the tendency to nervous agitation, insomnia, and nightmares. These are followed by hallucinations and profound mental troubles, which may lead to the Assize Court, or to the asylum, or to both." And: "Absinthe is a poison more powerful in murderous impulses than any other. Its victims sometimes run amok in provincial France. In a case under my notice a labourer, maddened by absinthe and armed with a long knife, rushed down a village street not far from Paris. . . Instances of the sort might be multiplied to show the effects of absinthe."*

Referring to the easy passage through both houses of the Legislature of the measure to prohibit absinthe, The Times corre. spondent says : "It is one of the most interesting manifestations of that new spirit which has arisen in France. It is significant that it excited no opposition amongst the public, and little amongst the trade. The latter only stipulated that there should be allowances made for the amount paid in excise on unconsumed stock." + That is to say, patriotism prevailed over pockets. We shall look in vain for any similar display of patriotism from the British representatives of "the trade." Their country's good seems always to be second to the good of the drink trade. General Joffre, Commander-in-Chief of the Allied Armies in France and Belgium, has issued a decree absolutely forbidding the sale of liquors to troops in the war zone. The only alcohol which will be allowed to the soldiers will be that issued as rations. Treating soldiers is also forbidden, and anyone, whether liquor-seller or not, who breaks this order will be court-martialled. "It is the duty of all patriots," says General Joffre in introducing the above order, "to fight alcoholism in all its forms. Everyone must understand that anything capable of diminishing the moral and material strength of our Army constitutes a real crime against

* See article by "Our Special Correspondent," Paris, in The Times, April 3, 1915.

† The Times, April 3, 1915. 
national defence in face of the enemy." Would that members of our Parliament would take to heart the solemn truth contained in that last sentence.

It is reported from Paris that the French Government intends to take most drastic action in dealing with alcohol during the war. Let us hope they will have the courage to go through with their proposals, and not allow such a lamentable fiasco as befell our Government recently. "The Petit Parisien states that the Government will very shortly introduce a Bill in the Chamber for the purpose of prohibiting in the most absolute manner the manufacture, sale, and consumption of alcohol in all its forms. Non-hygienic apéritifs, or drinks containing any proportion of alcohol whatever, will also be prohibited for the entire duration of the war." +

In view of the fact that in 1913 France consumed $1 \frac{1}{20}$ pints of "pure alcohol" per head of her population, this proposal, should it happily become law, will indeed reveal an act of national self-sacrifice worthy of the great struggle in which France and her Allies are engaged. Such determination to win would snatch victory from the very jaws of defeat.

Russia continues to provide excellent evidence of the value of prohibition, and particularly of increased thrift and comfort which follows in its train. Both the military and the civilians show the benefits to the most casual observer, and even newspapers which consistently have resisted attempts at legislative reform of the liquor traffic in this country, publish evidence collected by their correspondents on the spot concerning the blessings which prohibition has brought to Russia.

In articles published in the two preceding issues of this Joumal we have quoted testimonies as to the good behaviour of the Russian soldiers. The following statement goes to confirm what other observers have reported. It is from "Our Own Correspondent" of The Westminster Gazette. Writing from Warsaw he says : "The discipline of the troops seen by me on this front and in Galicia is good. This is true both as regards conduct of soldiers towards one another and towards the civil population, and as regards purely military discipline in battle. Naturally, there is no

- Daily Newos, April 10, 1915.

+ Pall Mall Gasette, May 7, 1915.

I See British Journal of Inebriety for January and April, 1915. 
intemperance; the prohibition against drink is absolute for all ranks, and it is rigidly carried out; but there is also no plundering, brawling, or ill-treatment of women." No student of the question will be surprised by this testimony.

The benefits to the social condition of the people in Russia still continue to grow, as witness Reuter's telegram sent to the English Press on May 26 from Petrograd: "During the period from September, 1914, to April, 1915, the State Savings Banks received deposits, the monthly total of which showed an average of 38 million roubles $(£ 3,800,000)$ as compared with scarcely a million roubles $(\$ 100,000)$ for the respective months of 1913 and 1914. This fact is ascribed to the absolute prohibition of the sale of spirits." $\dagger$ In other words, the total savings for the eight months before prohibition amounted to $\$ 800,000$, whilst in the eight months after prohibition they were $\$ 30,400,000$. This, of course, refers to deposits in the State Banks alone, and does not account for other methods of saving.

The Russian supplement of The Times of April last published an important article on "War, Vodka, and the Muzhik" which merits careful consideration. $\ddagger$

The obvious and serious lesson of the facts above set out is, that on the Continent men are sacrificing their appetites to the call of patriotism and national necessity, whilst we here in Great Britain seem to have chosen pocket interests and guzzling throats as our guides and governors, allowing the great call of national duty to fall into a secondary place. That, surely, is not the way in which the Great Struggle is to be won and our National Perils averted. May we become wise ere it is too late!

- Westminster Gasette, March 29, 1915.

† Evening News, May 27, 1915.

I Quotations from this article will be found in the Memorandum section of the present issue. 